\title{
COVID-19 salgınıyla ilişkili semptomların Türkiye'den gerçekleştirilen internet arama motoru sorgularının incelenmesi
}

\section{Investigation of internet search engine queries of the symptoms related to COVID-19 in Turkey}

\author{
느. Mevzi Esen \\ Sağlık Bilimleri Üniversitesi, Sağlık Bilişim Sistemleri Bölümü, İstanbul, Türkiye
}

Cite this article as / Bu makaleye atıf için: Esen MF. COVID-19 salgınıyla ilişkili semptomların Türkiye’den gerçekleştirilen internet arama motoru sorgularının incelenmesi. J Med Palliat Care 2021; 2(1): 7-14.

\begin{abstract}
ÖZ
Amaç: Bu çalışmada COVID-19 öncesi ve pandemi döneminde COVID-19 semptomlarına ilişkin Türkiye'den gerçekleştirilen internet arama motoru sorgulamalarının retrospektif olarak analiz edilmesi amaçlanmıştır.

Gereç ve Yöntem: Veriler Google Trends uygulaması kullanılarak elde edilmiştir. Kullanılan anahtar kelimeler Ankara Üniversitesi Tip Fakültesi tarafından hazırlanan COVID-19 kılavuzunda belirtilen klinik bulgulardan "ateş, halsizlik-yorgunluk, öksürük, boğaz ağrısı, kas ağrısı, ishal, baş ağrısı, sırt ağrısı, konjonktivit, bel ağrısı, nefes darlığı, koku ve tat kaybı” alınarak gerçekleştirilmiştir.

Bulgular: Türkiye'de resmi olarak ilk vakanın duyurulmasını izleyen günlerde COVID-19’la ilişkili en yüksek sorgu seviyelerine ulaşıldı. Resmî açıklamanın yapıldığı gün ilgili sorgular, bir önceki güne göre \%230 oranında artmış olup, resmî açıklamayı takip eden günde söz konusu sorguların yaklaşık \%66 oranında arttığı görüldü. COVID-19 öncesi ve COVID-19 dönemleri arasında; ateş, ishal, baş ağrısı, konjonktivit, öksürük, nefes darlığı, koku ve tat kaybı, boğaz ağrısı, sırt ağrısı ve kas ağrısı şikâyetlerini sorgulama sıklıkları arasında anlamlı bir farklılık tespit edildi $(\mathrm{p}<0,01)$.

Sonuç: İnternet arama motorlarında kullanılan anahtar kelimelerin aranma sıklığı COVID-19 döneminde, öncesi döneme göre anlamlı olarak artmaktadır. Salgınların ve etkilerinin önceden tahmin edilmesi amacıyla arama motoru sorgularının analizi, gerekli tedbirlerin alınması ve karar vericilerin sağlık hizmetlerini etkin olarak planlamalarına imkân sağlayabilir.
\end{abstract}

Anahtar Kelimeler: COVID-19, internet, semptomlar, halk sağlığı bilişimi

\begin{abstract}
Objective: In this study, we aimed a retrospective analysis of internet search engine queries related to the symptoms of COVID-19 from Turkey before and during the pandemic period.

Material and Method: The data were obtained using Google Trends. The keywords were "fever, weakness-fatigue, cough, sore throat, muscle pain, diarrhea, headache, back pain, conjunctivitis, low back pain, shortness of breath, loss of taste and smell" among the clinical findings of COVID-19.

Results: The queries related to COVID-19 symptoms reached the highest level following the official announcement of the first case in Turkey. The queries increased by $230 \%$ compared to the day before the announcement. The queries increased by approximately $66 \%$ compared to the previous day, following the official announcement. A significant difference was found between the frequency of the queries as fever, diarrhea, headache, conjunctivitis, cough, shortness of breath, loss of smell and taste, sore throat, back pain and muscle pain between pre-COVID-19 and COVID-19 periods $(\mathrm{p}<0.01)$.

Conclusion: The frequency of the queries increased significantly in the COVID-19 period compared to the pre-COVID-19 period. In order to predict outbreaks and their effects, the analysis of search engine queries can enable people to be informed in advance about the situations that may occur and to take the necessary measures before the pandemic. This can assist decision-makers in planning health services effectively. Keywords: COVID-19, internet, symptoms, public health informatics
\end{abstract}




\section{GIIRIŞ}

Amerika Birleșik Devletleri (ABD)'nde internet kullanıcılarının yaklaşık üçte biri, yaşadıkları hastalık semptomları hakkında internet arama motorlarını kullanarak kendi kendine teşhis koymaktadır (1). Başka bir çalışmada ise, ABD'de yetişkinlerin yaklaşık \%70'inin karşılaştıkları tıbbi problemlerin çözümünde internet ve mobil teknolojilerinden yararlanarak, elde ettikleri bilgiyi kullandıkları belirtilmektedir (2). Sadece Birleşik Krallık ulusal çevrimiçi hasta portalına aylık 15 milyonun üzerinde ziyaret gerçekleşmekte olup, belirli hastalık semptomları taşıyanlar kendi kendilerine teșhis koymakta ve olası hastalıkları konusunda çözüm yolları aramak amacıyla arama motorlarıyla sorgu gerçekleştirmektedir (3).

Gelişen bilgi ve iletişim teknolojileri sayesinde, kişiler kendilerinde gözlemledikleri fonksiyonel ve duygusal durumu, yaşam kalitesini etkileyen hastalık semptomlarını veya hastalıklarına ilişkin tecrübelerini internet aracılığıyla paylaşmakta, içinde bulundukları durumun sebepsonuçları ve alternatif tedavi yöntemleri üzerinde çok yönlü araştırmalar gerçekleştirmektedir. Bu durum ayrıca, tıbbi bilgilerin erişilebilirliğini de arttırmakta ve kişinin hastalıklar konusunda öz bilinç geliştirmesine ve ihtiyaç duyduğu sosyal desteği elde ederek sağlık sonuçlarının iyileștirilmesine yardımcı olmaktadır (4). Ayrıca, hastalar tarafından gerçekleştirilen internet sorguları ve sosyal medya paylaşımları, sağlık kuruluşunun pazar konumunu güçlendirmek, marka yönetimi ve iyileştirilmiş hizmet sunumu için firsat yaratmakta ve sağllk sistemine geniş bir yelpazede etki etmektedir (5). Öte yandan, kişinin sağlık okur-yazarlığının düşük olması durumunda ise, kişinin kendi durumunu doğru bir biçimde tanımlayamaması, gösterdiği semptomlara ilişkin ulaştığı bilginin güvenilir olmaması veya kişi tarafından ulaşılan sağlık bilgisinin eleștirel bir şekilde değerlendirilememesi ve ulaştığı çözümün kendi bulunduğu duruma uygulanabilirliğinin olmaması, çevrimiçi yaygınlığı giderek artan sağlık bilgilerinin dikkatli değerlendirilmesini de gerektirmektedir (6).

Global internet ve sosyal medya kullanıcı sayısının 4,5 milyarı aştı̆̆1 da düşünüldügünnde, hastaların internet siteleri ve sosyal medya platformları aracilığıla güncel tıbbi öykülerinin başta olmak üzere; hasta hikayesi, sosyal ve ailesel öykülerin paylaşımı ve bunlarla ilgili çözüm arayışları, sağlıkta iletişim teknolojilerinin önemine dikkat çekmektedir (7). Nitekim, hastaların semptomlarını sorgulamak suretiyle ve tıbbi desteğe ihtiyaç gerekip gerekmediğini öğrenebilmeleri amacıyla yaygın olarak internet arama motoru sorgularından yararlandıkları belirtilmektedir (8). Özellikle mevsimsel grip gibi birçok epidemik hastalık semptomlarının izlenmesi amacıyla internet arama motoru sorguları değerlendirilmekte; riskin erken tespiti ve sağllk hizmetlerinin planlanması, söz konusu bilgilere dayalı olarak gerçekleştirilmektedir (9).
Gerçekleştirilen kesitsel çalışmalarda, hastalar tarafından yapılan çevrimiçi paylaşımların ve arama motoru sorgularının kişilerin kendi sağlığını ve bakımını yönetme bilgi ve becerisini teşvik ettiği; hasta anlayışını geliştirdiği ve karşlıklı iletişimle doktor-hasta iş birliğini etkinleștirebileceği belirtilmektedir (10). Bu durum, arama verilerinin toplum sağlığı açısından önemli olan hastalıkların erken tanınması ve gelişebilecek hastalık ve ölümlerin azaltılması amacıyla yapılan sağlık taramasının bir aracı olarak kullanılabileceğini göstermektedir. Sonuç olarak, kullanıciların internet sorguları ve sosyal medya paylaşımlarıyla toplanan tıbbi bilgiler analiz edilerek, bulaşıcı hastalıkların takibi, morbidite ve mortalite başta olmak üzere; kanser, diyabet, hipertansiyon, kadın hastalıkları, doğum, ruh sağlığı ve psikiyatri gibi salgın olmayan hastalıklarla ilişkili medikal kondisyonların değerlendirilmesi gibi halk sağlı̆̆ıyla yakından ilişkili konuların etkin bir şekilde planlanması sağlanmaktadır $(11,12)$.

Son yllarda, internet bilgi kaynaklarından elde edilen veriler epidemiyolojik araştırmalar için değerli bir araç olarak kabul edilmektedir. Örneğin, belirtilen anahtar kelimelere göre coğrafi ve zamansal modeller hakkında veri üreten Google Trends platformu, hem farklı klinik ortamlarda ve sosyal çevrelerde daha az yer alan fakat yaygın olarak tespit edilen hastalıkların, hem de söz konusu ortamlarda sıkça yer alan fakat yaygın olmayan hastalıkların araştırılması amacıyla kullanılmaktadır (13). Google, Facebook ve Twitter gibi çevrimiçi kaynaklar aracilı̆̆ıyla seçilen anahtar kelimelerle veya konulara göre gerçek zamanlı olarak elde edilen veriler veya trendler, salgın döneminde nüfusun davranışı, sağlık analizi ve tahmini üzerine değerli bilgiler sunmaktadır (14).

COVID-19 salgını sebebiyle dünya genelinde insanlar, evde kalmaya ve internet aracilı̆̆gyla iş ve iletişimlerini devam ettirme zorunluluğu ile karşı karşıya kalmaktadır. Salgın döneminin etkisiyle, hastalığın önlenmesi ve izlenmesi konusunda bilgi ihtiyacı arttığ 1 gibi, sağlık hizmetlerinin planlanmasındaki öncelikler COVID-19'un teşhis ve tedavisine odaklanmaktadır. Bu durum, çeşitli sağlık problemleri dolayısıyla hastaneye başvuramayan bireylerin internet üzerinden kendi sağlık durumlarına ilişkin değerlendirme arayışlarında artışı da beraberinde getirmektedir (15). Örneğin, COVID-19 salgınının halk sağlığı politikaları üzerindeki etkisi ve yardımcı epidemiyolojik veri sağlamak amacıyla gerçekleştirilen bir çalışmada, COVID-19 pandemisi bir dijital epidemiyoloji olgusu olarak ele alınarak, pandeminin gelecekteki etkisinin öngörülebilmesi açısından bir metodoloji önerilmiştir. Buna göre, COVID-19 konusunda çevrimiçi arama eğilimleri, hastalı̆̆ın klinik belirtilerini tam anlamıyla yansıtmakta olup, sahada gözlenen vakalarla söz konusu durum arasında güçlü bir ilișki bulunmaktadır 
(16). Gerçekleştirilen bir diğer çalışmada ise, Google Trends arama verileri ile İtalyada yaşanan COVID-19 vakaları değerlendirilmiş olup, COVID-19'un gelecekteki durumunu tahminlemede infodemiyoloji olarak da adlandırılan internet arama motoru sorgularının önemli bir araç olduğu belirtilmiștir (17). Başka bir çalıșmada ise, COVID-19 salgını ile ilgili olarak İtalya'da çevrimiçi olarak gerçekleștirilen arama motoru sorguları ele alınmış olup, bölgesel olarak dezenfektan, yüz maskeleri ve sağlık bültenleri gibi koruyucu tedbirlerin yanı sıra; Covid semptomlarına olan ilgi düzeyinde ciddi bir artış yaşandığ1 tespit edilmiştir (15). COVID-19 ile ilişkili Google arama motoru sorgularıly ülkeler tarafindan raporlanan COVID-19 vaka sayılarının anlamlı bir ilişkiye sahip olduğu ve COVID-19 konusundaki sorguların vaka sayılarının pik yaptığı tarihten yaklaşık 11,5 gün önce en yüksek seviyede olduğu tespit edilmiştir. Ayrıca, Google Trends uygulamasının COVID-19 salgınının ilerleyişini takip için kullanılabilecek en etkin analitik araçlardan biri olduğu belirtilmiştir (18).

Bu çalışmada, COVID-19 ile ilişkilendirilen semptomların Google arama motoru aracilığıla 01.12.2018-01.12.2020 tarihleri arasında Türkiye'den gerçekleștirilen sorgularının analiz edilerek, kullanıcıların ilişkili arama davranışlarının tespit edilmesi amaçlanmıştır.

\section{GEREÇ VE YÖNTEM}

Çalışmada kullanılan veri Google Arama Trendlerinden elde edilmiştir. Arama için anahtar kelimeler olarak, Ankara Üniversitesi Tip Fakültesi tarafından hazırlanan COVID-19 kılavuzunda belirtilen klinik bulgulardan "ateş, halsizlik-yorgunluk, öksürük, boğaz ağrısı, kas ağrıs1, ishal, baş ağrısı, sırt ağrısı, konjonktivit, bel ağrısı, nefes darlığı, koku ve tat kaybı" kullanılarak arama gerçekleştirilmiştir (19). Anahtar kelimelere göre 01.12.2018-01.12.2020 tarihleri arasinda Türkiyéden gerçekleştirilen COVID-19 bulguları ve ilişkili sorgular ele alınarak, R (versiyon 4.0.2) açık kaynak kodlu programla istatistiksel olarak değerlendirilmiştir. Arama sonuçlarının daha iyi anlaşılabilmesi amacıyla veri seti, Türkiye'den gerçekleştirilen COVID-19 sorgularının ani artış gösterdiği 20 Ocak 2020 tarihi ve sonrası "COVID-19 dönemi", 20 Ocak 2020 öncesi dönem ise "COVID-19 öncesi” olarak adlandırılarak, her iki dönem arasındaki farklılıklar istatistik testler ve tablolarla belirlenmiştir.

\section{İstatistiksel Yöntem}

Çalışmada, yukarıda belirtilen anahtar kelimelerle gerçekleştirilen sorguların söz konusu zaman içerisindeki değişimini inceleyebilmek amacıyla, aramanın gerçekleştirildiği terime ilişkin Türkiye'den gerçekleștirilen tüm sorgular içerisindeki nispi ölçütü ifade eden arama hacmi (zaman içerisinde gösterilen ilgi) verisi kullanılmıştır. $\mathrm{Bu}$ veri, gerçekleştirilen aramaya zaman içerisinde gösterilen ilgiyi belirtmekte olup, Google arama motoru üzerinden tüm konularda söz konusu zaman aralıkları ve konumlardan yapılan tüm aramaların bir oranı olarak değerlendirilmektedir. Zaman içerisinde arama sorgularında artış ve azalış yaşandığı için, Google Trends tarafından sağlanan veriler normalize edilmekte olup, belirtilen zaman ve mekân içerisinde gerçekleştirilen sorguların en yüksek olduğu seviye için maksimum " 100 " değeri atanmaktadır.

Çalışmada, sağlık kategorisinde yapılan tüm sorgular içerisinde COVID-19 ile ilişkili sorguların oranını ifade etmek amacıyla alan grafiği, semptomlara yönelik anahtar kelimelerin sorgu popülaritelerinin 01.12.201801.12.2020 tarihleri arasındaki değişimini göstermek için ise tablo kullanılmıştır. COVID-19 öncesi ve COVID-19 döneminde gerçekleştirilen sorgu hacimlerinin ortalamaları arasındaki anlamlllk, verinin normal dağılmadığ 1 durumlarda kullanılan parametrik olmayan Mann Whitney U testi ile gerçekleștirilmiştir. Arama sorguları arasındaki ilişkinin tespit edilebilmesi amacıyla, Spearman Sıra korelasyonu analizi gerçekleștirilmiș olup, korelasyon katsayılarının anlamlılığı için olasılık (p) değerleri hesaplanmıștır. İstatistiksel anlamlılık düzeyi $\mathrm{p}<0,01$ olarak kabul edilmiştir.

\section{BULGULAR}

COVID-19 ile ilişkili arama motoru sorgularının değerlendirilmesi amacıyla, COVID-19 salgını öncesi dönemle, salgın dönemindeki trend Grafik-1'de verilmiştir. Grafikte, 01.12.2018-01.12.2020 tarihleri arasında "COVID-19, korona, COVID, korona virüsü, korona" anahtar kelimeleriyle Türkiyeden gerçekleștirilen COVID-19'la ilişkili sorgu kayıtları ele alınmıştır. Buna göre, Ocak 2020 döneminin ikinci haftasından sonra COVID-19 ilişskili sorgularda ciddi artış göze çarpmaktadır. Örneğin, 20 Ocak 2020 tarihinde COVID-19 ile ilişkili yukarıda belirtilen anahtar kelimelerle gerçekleştirilen sorgular, bir önceki güne oranla yaklaşık 3,5 kat artış göstermiş olup, Mart ayının ilk haftasına kadar söz konusu artış sağlık kategorisi sorguları içerisinde de sinırlı kalmıştır. Türkiye’de resmi olarak 10.03.2020 tarihinde ilk vakanın duyurulmasını izleyen günlerde en yüksek sorgu seviyelerine ulaşılmıştır. Resmî açıklamanın yapıldığı gün korona ilişkili sorgu sayısı bir önceki güne $\% 230$ oranında artmış olup, resmî açıklamayı takip eden 11.03.2020 tarihinde bir önceki güne göre söz konusu sorgular yaklaşı \%66 oranında artmıștır. 22 Mart 2020 tarihinden sonra azalışa geçen sorgular, Temmuz ayının üçüncü haftasına kadar inişli ve çıkışlı bir seyir izlemiştir. Ağustos ayının ilk haftası ve Kasım ayının ortası itibariyle aramalarda tepe noktaları tekrar izlenirken, Kasım ayının ikinci haftasından itibaren hızlı bir düşüş gözlemlenmektedir. 




Grafik 1. COVID-19 hakkında google arama motorunda yapılan aramaların dağılımları

Tablo 1'de en s1k raporlanan COVID-19 semptomlarına ilişkin Türkiye'den gerçekleştirilen aramaların, COVID-19 aramalarının ilk olarak artış gösterdiği 20 Ocak 2020 öncesi ve sonrası dönemdeki dağılımları incelendi. Arama trendinin incelenebilmesi amaciyla, COVID-19 öncesi döneme ilişkin tarih aralığ 2018'den itibaren ele alındı. Ateş, ishal, baş ağrısı, konjonktivit, öksürük, nefes darlığı, koku ve tat kaybı, boğaz ağrısı, sırt ağrısı ve kas ağrısı şikayetlerini sorgulama sıklıkları arasında iki dönem arasında anlamlı bir farklılık tespit edilmiştir $(\mathrm{p}<0,01)$. COVID-19 öncesi ve COVID-19 dönemleri arasinda, halsizlik- yorgunluk, bel ağrısı semptomları sorgusu açısından anlamlı bir fark bulunamadı ( $\mathrm{p}>0,01)$.

Şikayetlerin arama motorunda sorgulanma popülaritelerinin zamana göre dağılımları incelendiğinde, en sık aramanın ishal ve ateş semptomu için yapıldığı görüldü (Tablo 2). Mart ve Nisan aylarında ateş sorgulaması ishal sorgulaması sıklığının önüne geçtiği gözlendi. Ateş aramasının Nisan ayında en yüksek değere ulaştığı tespit edildi. Koku ve tat kaybı ve konjonktivit sorgusunun Ocak 2020'den önce çok düşük düzeyde yapıldığı veya yapılmadığ 1 tespit edildi (Tablo 2). Aynı şekilde, boğaz ağrısına ilişkin sorgulamanın Mart ayının ikinci haftasından itibaren yükselişe geçerek en yüksek değerine Nisan ayı başında ulaştığı sonucuna ulaşıldı.

\begin{tabular}{|c|c|c|c|c|}
\hline Semptomlar & Aralık & Temmuz & Ocak & Temmuz \\
\hline Ateş & 33,88 & 31,36 & 51,62 & 41,31 \\
\hline Baş ağrısı & 24,55 & 24,72 & 27,96 & 30,24 \\
\hline Konjonktivit & 1,42 & 1,16 & 1,45 & 2,82 \\
\hline Öksürük & 21,55 & 17,91 & 22,29 & 13,39 \\
\hline Nefes darlığ 1 & 3,53 & 3,40 & 7,34 & 6,62 \\
\hline Koku kaybı & 0,33 & 0,11 & 0,68 & 3,15 \\
\hline Tat kaybı & 0,10 & 0,05 & 0,67 & 2,15 \\
\hline $\begin{array}{l}\text { Halsizlik- } \\
\text { yorgunluk }\end{array}$ & 7,54 & 7,70 & 8,50 & 9,04 \\
\hline Boğaz ağrısı & 6,08 & 4,90 & 10,27 & 9,27 \\
\hline Sırt ağrısı & 6,30 & 6,43 & 8,41 & 10,82 \\
\hline Kas ağrısı & 2,85 & 3,01 & 3,31 & 3,36 \\
\hline Bel ağrısı & 10,18 & 10,41 & 9,68 & 11,38 \\
\hline
\end{tabular}

\begin{tabular}{|c|c|c|c|c|c|}
\hline \multirow[t]{2}{*}{ Semptomlar } & \multicolumn{2}{|c|}{$\begin{array}{l}\text { COVID-19 öncesi dönemde ortalama sorgu } \\
\text { hacmi skoru (n: } 59 \text { hafta) }\end{array}$} & \multicolumn{2}{|c|}{$\begin{array}{l}\text { COVID-19 döneminde ortalama sorgu hacmi } \\
\text { skoru (n: } 48 \text { hafta) }\end{array}$} & \multirow[t]{2}{*}{$\mathbf{p}$} \\
\hline & Ortalama & Std, Sapma & Ortalama & Std, Sapma & \\
\hline Ateş & 33,513 & 7,252 & 46,297 & 15,845 & $<0,01$ \\
\hline İshal & 52,847 & 13,311 & 60,708 & 13,955 & $<0,01$ \\
\hline Başağrısı & 24,675 & 2,238 & 29,178 & 5,189 & $<0,01$ \\
\hline Konjonktivit & 1,291 & 0,536 & 2,146 & 1,190 & $<0,01$ \\
\hline Öksürük & 20,787 & 9,180 & 16,990 & 9,006 & $<0,01$ \\
\hline Nefes darlığ & 3,569 & 0,872 & 7,167 & 3,026 & $<0,01$ \\
\hline Koku alamama & 0,220 & 0,279 & 1,944 & 1,640 & $<0,01$ \\
\hline Tat alamama & 0,071 & 0,317 & 1,439 & 1,039 & $<0,01$ \\
\hline Halsizlik-yorgunluk & 7,602 & 1,784 & 8,793 & 2,188 & $>0,01$ \\
\hline Boğaz ağrısı & 5,614 & 1,875 & 9,844 & 3,825 & $<0,01$ \\
\hline Surt ağrisı & 6,415 & 1,309 & 9,658 & 3,152 & $<0,01$ \\
\hline Kas ağrısı & 2,928 & 0,774 & 3,353 & 0,968 & $<0,01$ \\
\hline Bel ağrisı & 10,223 & 1,478 & 10,577 & 1,952 & $>0,01$ \\
\hline
\end{tabular}


Anahtar sözcüklerin birlikte sorgulanma durumuna bakıldığında; ateş ve nefes darlığının birlikte sorgulanma korelasyonu, korona öncesi dönemde anlamsizken, korona döneminde yaklaşık \%75 korelasyon tespit edildi. Korona öncesi dönemde baş ağrısı semptomu sorgusunun yalnızca öksürük sorgusuyla ilişkisi anlamlı olarak bulunurken, korona döneminde öksürükle söz konusu sorgulama arasında anlamlı ilişki bulunamamış olup ( $>0,01$ ), nefes darlığı, tat kaybı, halsizlik-yorgunluk, sırt, bel ve kas ağrısı sorgularıyla korelasyonu anlamlı bulundu. Korona döneminde öksürük şikâyeti ateş, tat ve koku kaybı, boğaz ve bel ağrısı sorgulamaları ile birlikte artmış olup, sorgular arasındaki ilişkiler anlamlı bulundu (Tablo 3). Ateș sorgusu, korona öncesi dönemde öksürük sorgularıla yüksek ilişkiliyken, korona döneminde boğaz ağrısıyla en yüksek ilişkili sorgu $(\% 63,7)$ olarak gözlendi. Konjonktivit ile gerçekleştirilen sorguların ilişkisi korona öncesi dönemde anlamsız bulunurken, korona dönemi için konjonktivit sorgularıyla ishal, tat ve koku kaybı, halsizlik ve yorgunluk sorguları arasında anlamlı ilişki tespit edildi.

COVID-19 öncesi ve COVID-19 döneminde anahtar kelimelerle yapılan arama şablonlarının en sık olanları Tablo 4'te verildi. Örneğin, korona öncesi dönemde "ishal" anahtar kelimesiyle yapılan sorgularlailișkili olarak en fazla sorgulananlar" ishali kesen yiyecekler, sürekli ishal, evde ishal nasıl geçer” iken, korona döneminde söz konusu anahtar kelimeyle ilişkili sorguların korona ekseninde yapıldığı göze çarpmaktadır. Koku ve tat kaybına ilişkin korona öncesinde ilişkili sorgu verisine rastlanmamış olup, korona döneminde koku ve tat kaybı sorguları korona ile bağdaştırılmıştır.

Tablo 3. Semptomların eş zamanlı sorgulanmaları arasındaki ilişki

\begin{tabular}{|c|c|c|c|}
\hline \multicolumn{2}{|c|}{ İlişkili semptomlar } & \multirow{2}{*}{$\begin{array}{c}\begin{array}{c}\text { Korona dönemi öncesi korelasyon } \\
\text { katsayısı (p değeri) }\end{array} \\
0,704(<0,01)\end{array}$} & \multirow{2}{*}{$\begin{array}{c}\begin{array}{c}\text { Korona dönemi korelasyon } \\
\text { katsayısı (p değeri) }\end{array} \\
0,609(<0,01)\end{array}$} \\
\hline \multirow{3}{*}{ Ateş } & Öksürük & & \\
\hline & Nefes darlığ 1 & $0,046(>0,01)$ & $0,746(<0,01)$ \\
\hline & Boğaz ağrısı & $0,339(<0,01)$ & $0,886(<0,01)$ \\
\hline \multirow{5}{*}{ İshal } & Ateş & $-0,233(>0,01)$ & $0,375(<0,01)$ \\
\hline & Konjonktivit & $0,053(>0,01)$ & $0,637(<0,01)$ \\
\hline & Öksürük & $-0,620(<0,01)$ & $-0,169(>0,01)$ \\
\hline & Halsizlik-yorgunluk & $0,560(<0,01)$ & $0,703(<0,01)$ \\
\hline & Boğaz ağrısı & $-0,353(<0,01)$ & $0,401(<0,01)$ \\
\hline \multirow{7}{*}{ Baş ağrısı } & Öksürük & $0,324(<0,01)$ & $-0,194(>0,01)$ \\
\hline & Nefes darlığı & $0,202(>0,01)$ & $0,494(<0,01)$ \\
\hline & Tat kaybı & $0,194(>0,01)$ & $0,418(<0,01)$ \\
\hline & Halsizlik-yorgunluk & $-0,177(>0,01)$ & $0,415(<0,01)$ \\
\hline & Sirt ağrısı & $0,186(>0,01)$ & $0,481(<0,01)$ \\
\hline & Bel ağrısı & $0,110(>0,01)$ & $0,418(<0,01)$ \\
\hline & Kas ağrısı & $-0,146(>0,01)$ & $0,507(<0,01)$ \\
\hline \multirow{3}{*}{ Konjonktivit } & Tat kaybı & $0,069(>0,01)$ & $0,573(<0,01)$ \\
\hline & Koku kaybı & $0,084(>0,01)$ & $0,560(<0,01)$ \\
\hline & Halsizlik-yorgunluk & $0,144(>0,01)$ & $0,442(<0,01)$ \\
\hline \multirow{3}{*}{ Öksürük } & Tat kaybı & $0,146(>0,01)$ & $0,470(<0,01)$ \\
\hline & Boğaz ağrısı & $0,461(<0,01)$ & $0,565(<0,01)$ \\
\hline & Bel ağrısı & $-0,181(>0,01)$ & $0,371(<0,01)$ \\
\hline Nefes darlığ & Boğaz ağrısı & $-0,041(>0,01)$ & $0,753(<0,01)$ \\
\hline \multirow{3}{*}{ Koku kaybı } & Tat kaybı & $0,101(>0,01)$ & $0,883(<0,01)$ \\
\hline & Sırt ağrısı & $-0,070(>0,01)$ & $0,609(<0,01)$ \\
\hline & Bel ağrısı & $-0,012(>0,01)$ & $0,401(<0,01)$ \\
\hline \multirow{2}{*}{ Tat kaybı } & Sırt ağrısı & $0,280(<0,01)$ & $0,602(<0,01)$ \\
\hline & Bel ağrısı & $0,334(<0,01)$ & $0,399(<0,01)$ \\
\hline Halsizlik-yorgunluk & Kas ağrısı & $0,226(>0,01)$ & $0,375(<0,01)$ \\
\hline Sirt ağrısı & Bel ağrısı & $0,025(>0,01)$ & $0,407(<0,01)$ \\
\hline
\end{tabular}




\begin{tabular}{|c|c|c|}
\hline Semptom & $\begin{array}{l}\text { Korona öncesi dönemde semptomla ilişkili olarak en sık } \\
\text { gerçekleştirilen sorgular ( } n=48 \text { hafta) }\end{array}$ & $\begin{array}{l}\text { Korona sonrası dönemde semptomla ilişkili olarak en } \\
\text { sık gerçekleştirilen sorgular ( } n=48 \text { hafta) }\end{array}$ \\
\hline Ateş & $\begin{array}{l}\text { bebeklerde ateş, ateş nasıl düşürülür, yüksek ateş, ateş basması, } \\
\text { çocuklarda ateş }\end{array}$ & $\begin{array}{l}\text { COVID ateş, korona belirtileri ateş, koronada ateş, korona } \\
\text { ateş kaç derece, korona ateş sınırı }\end{array}$ \\
\hline Baş ağrısı & $\begin{array}{l}\text { baş ağrısı nasıl geçer, baş ağrisı neden, mide bulantısı ve baş } \\
\text { ağrısı, baş ağrısı nedenleri, şiddetli baş ağrısı, sürekli baş ağrısı }\end{array}$ & $\begin{array}{l}\text { baş ağrısı korona, korona baş ağrısı, COVID baş ağrisı, } \\
\text { korona virüs baş ağrısı, COVID-19 baş ağrısı, baş ağrısı } \\
\text { korona belirtisi mi }\end{array}$ \\
\hline İshal & $\begin{array}{l}\text { ishali kesen yiyecekler, sürekli ishal olma, ishalin sebepleri } \\
\text { nelerdir, ishal geçirme, ishal evde nasıl geçer çözüm, yeşil } \\
\text { dışkılama ishal }\end{array}$ & $\begin{array}{l}\text { korona ishal, korona ishal belirtisi, korona belirtileri ishal, } \\
\text { ishal korona belirtisi mi, korona virüs ishal, ishal COVID } \\
\text { belirtisi mi }\end{array}$ \\
\hline Konjonktivit & $\begin{array}{l}\text { konjonktivit nedir, alerjik konjontivit, viral konjonktivit, akut } \\
\text { konjonktivit, konjonktivit reçete }\end{array}$ & $\begin{array}{l}\text { konjonktivit nedir, korona belirtileri, COVID belirtileri, } \\
\text { COVID-19 belirtileri, korona belirtileri }\end{array}$ \\
\hline Öksürük & $\begin{array}{l}\text { öksürük şurubu, kuru öksürük, öksürüğe ne iyi gelir, öksürük } \\
\text { nassl geçer, öksürük balgam, bebeklerde öksürük }\end{array}$ & $\begin{array}{l}\text { öksürük korona, kuru öksürük korona, koronada öksürük, } \\
\text { kuru öksürük nasıl olur, öksürük korona belirtisi mi, } \\
\text { sadece öksürük korona belirtisi mi? }\end{array}$ \\
\hline Nefes darlığ 1 & $\begin{array}{l}\text { nefes darlığı nedenleri, nefes darlığı belirtileri, nefes darlığı } \\
\text { nedir, nefes darlığı nasıl geçer, akciğer kanseri, nefes darlığında } \\
\text { hangi bölüme gidilir? }\end{array}$ & $\begin{array}{l}\text { korona nefes darlığı, nefes darlığ korona, COVID-19 nefes } \\
\text { darlığı, farenjit nefes darlığı, koronada nefes darlığı }\end{array}$ \\
\hline Koku kaybı & - & $\begin{array}{l}\text { korona koku alamama, koku alamama korona belirtisi mi, } \\
\text { gripte tat ve koku alamama, koku alamama sebepleri }\end{array}$ \\
\hline Tat kayb1 & - & $\begin{array}{l}\text { koronada tat kaybı, COVID tat kaybı, COVID tat koku } \\
\text { kaybı, tat ve koku kaybı ne zaman geçer }\end{array}$ \\
\hline Halsizlik & $\begin{array}{l}\text { halsizlik yorgunluk, halsizlik mide bulantısı, halsizlik baş ağrısı, } \\
\text { halsizlik nedenleri, sürekli halsizlik, bacaklarda halsizlik }\end{array}$ & $\begin{array}{l}\text { korona halsizlik, halsizlik korona belirtisi mi, halsizlik } \\
\text { uyku hali, korona halsizlik, halsizlik ve baş ağrısı }\end{array}$ \\
\hline Boğaz ağrısı & $\begin{array}{l}\text { boğaz ağrısına ne iyi gelir, boğaz kulak ağrısı, boğaz ağrısı } \\
\text { öksürük, kulak ağrısı, geçmeyen boğaz ağrısı }\end{array}$ & $\begin{array}{l}\text { korona boğaz ağrisı, boğaz ağrısı korona, boğaz ağrisı } \\
\text { COVID, korona belirtileri boğaz ağrısı, koronada boğaz } \\
\text { ağrisı nasıl olur }\end{array}$ \\
\hline Sirt ağrısı & $\begin{array}{l}\text { sırt ağrisı nedenleri, sırt ağrısı nasıl geçer, sol sırt ağrısı, } \\
\text { hamilelikte sırt ağrıs1, boyun ve sırt ağrısı, bel ve sırt ağrısı }\end{array}$ & $\begin{array}{l}\text { korona sırt ağrısı, sırt ağrısı COVID, sırt ağrısı nasıl geçer, } \\
\text { sırt ağrısı kalp, hamilelikte sırt ağrısı, mide ve sırt ağrısı }\end{array}$ \\
\hline Kas ağrısı & $\begin{array}{l}\text { kas ağrısı nasıl geçer, kas ağrısı belirtileri, kas ağrısı nedenleri, } \\
\text { spordan sonra kas ağrısı }\end{array}$ & COVID kas ağrısı, eklem ağrısı, spor sonrası kas ağrısı \\
\hline Bel ağrısı & $\begin{array}{l}\text { bel ağrısı için ne iyi gelir, bel fitı̆̆ı ağrısı, bel fitı̆̆ı, hamilelikte } \\
\text { bel ağrısı, bel ağrısı neden olur, bel ağrısı hamilelik belirtisi mi }\end{array}$ & $\begin{array}{l}\text { bel ağrısı korona, COVID bel ağrısı, korona bel ağrısı, } \\
\text { korona bel ağrısı yapar mı, bel ağrısı için egzersizler, bel } \\
\text { ağrısı hamilelik belirtisi mi }\end{array}$ \\
\hline
\end{tabular}

\section{TARTIŞMA}

Halk sağlığ için yapılan internet araştırmalarının son 10 yılda hızla arttığı görülmüştür. Son birkaç yıl içinde yaşanan hızlı gelişmelerde, internet aramaları üzerine yapılan araştırmalarda bu aramaların halk sağ lığı üzerine etkisi olduğu gözlenmiştir (20). İnsanların doktora gitmeden önce semptomlarını internetten arattıkları da bilinmektedir (21). Bir çalışmada, Google arama verileri ile COVID-19 hakkında altı haftalık bir zaman çizelgesinde anahtar kelimeleri kullanarak ortaya çıkacak önemli noktaların tahminlerini belirleyebildiklerini tespit edilmiştir (22). Bu kapsamda COVID-19 pandemi döneminde Türkiyede insanların internet arama motorunda arama yaptıkları başlıklar tartışılacaktır.

Çalışmada, ilk vakanın resmi olarak duyurulmasından sonraki gün, COVID-19 ilişkili sorguların bir önceki güne göre yaklaşık \%66 oranında arttığı tespit edildi. ABD örnekleminde gerçekleştirilen bir çalışmada ise, ilk COVID-19 vakasının duyurulduğu günden bir gün sonra "coronavirus" anahtar kelimesiyle gerçekleştirilen aramaların \%36 oranında artış gösterdiği ve kişilerin bulundukları eyaletlerde ilan edilen ilk COVID-19 vakalarının hemen sonrasinda COVID-19 semptomları, maske, karantina, eğitime ara verme, koruyucu ilaçlar ve dezenfektanlar gibi halk sağlığı planlamasını ilgilendiren konularda yoğun olarak arama gerçekleştirdikleri tespit edilmiştir (23). Bu durum Türkiye'den gerçekleştirilen COVID-19 aramalarına daha yüksek oranda ilgi gösterildiğine işaret etmektedir.

Çalışmada, COVID-19 ile ilişkili anahtar kelimeler için internet aramalarının Mart ayının ilk haftasına kadar söz konusu artışın sağlık kategorisi sorguları içerisinde de sınırlı kaldığı; Mart ayının ilk haftasında COVID-19 ile ilgili arama sıklığının artmaya başladığı ve Mart ayının üçüncü haftasından itibaren en yüksek seviyeye ulaşıldığ çalışmada COVID-19'un, arama motorlarını kullanarak salgının 1-2 hafta önce tahmin edilebileceği gösterilmiş olup, COVID-19'un yayılmasını önlemek için salgının gelişimini olabildiğince erken tahmin etmenin önemi vurgulanmıştır (14). Başka bir çalışmada ise, salgının dijital alanda dünya çapında semptom aramalarının gerçek dünyadaki vakalar ve ölümlerle ilişkilendirildiği, internet armalarının gerçek dünyadaki vakalardan ve ölümlerden birkaç gün ile birkaç hafta öncesinden geldiği bulunmuştur (16). 
Çalışmada ateş sorgulamasının Aralık 2019'da Aralık 2018'e göre daha fazla sorgulandığ 1 , ikinci dalga olarak Mart ayının başında tekrar yüksek yoğunlukta aratılmaya başlandığ 1 tespit edilmiştir. Ateş semptomuyla ilişkili sorguların 2020 yılı mart ayının ilk haftasından itibaren artışa geçtiği ve Nisan ayında en yüksek değere ulaştığ 1 bulunmuştur. Bu tarih, Türkiye'de ilk COVID-19 vakasının tespit tarihi olan 10.03.2020 tarihinden yaklaşık on gün önceye denk gelmektedir. İtalyảda gerçekleştirilen bir çalışmada ise bir önceki mevsimsel grip sezonu (Aralık 2018-Nisan 2019) ile 2019-2020'nin aynı aylarında "öksürük" ve "ateş" Google aramaları analiz edilmiş olup, 2019-2020 sezonunda bir önceki yıla göre oldukça fazla arama yapıldığını tespit edilmiștir (17). Arama motorlarında yapılan sorgulamaların takip edilerek yaşanılacak salgınların öncesinde sağlık sistemini uyarmak için kullanılabilir.

Çalışmada ateş, ishal, öksürük ve baş ağrısı arama motorunda en sik aratılan semptomlar olarak tespit edildi. COVID-19'un en sık bulguları ateş, kuru öksürük, iştahsızlık, kas ağrısı, nefes darlığı bulunmuş, baş ağrisı, boğaz ağrisı, burun akıntısı, ishal daha az olarak saptanmıştır (24). Aratılan semptomların bulgularla ishal dışında uyumlu olduğu görülmektedir.

Türkiye'den gerçekleştirilen sorgular içerisinde, koku kaybı, tat kaybı ve konjonktivit sorgusunun Ocak 2020'den önce çok düşük seviyede gerçekleştirildiği, Mart ayının ilk haftasından itibaren koku ve tat kaybı sorgusunun artış gösterdiği tespit edildi. Çalışmamızın bulgularılyla paralel olarak, 17 farklı ülke verisiyle yapılan bir çalışmada ise, COVID-19 semptomlarından olan koku ve tat kaybina ilişkin Google sorgularında anlamlı derecede artışlar meydana geldiği tespit edilmiştir (25).

COVID-19 öncesi ve COVID-19 döneminde semptomlara ilişkin anahtar kelimelerle yapılan sorgular incelendiğinde; COVID-19 öncesi dönemde kişiler, semptomlarını nasıl iyileştirebileceklerini sorgulatan arama kelimelerini sıklıkla kullanılırken; COVID-19 döneminde söz konusu semptomların COVID-19 ile birleştirilerek sorgulanmaya başladığ 1 tespit edildi. Ayrıca, COVID-19 döneminde anahtar kelimelerle yapılan sorgularla ilişkili sorgular arasında, "semptomların nasıl tedavi edileceğine ilişkin" aramalara rastlanmadi. Örneğin, COVID-19 öncesi dönemde ateş hakkında yapılan en sık sorgulama "Ateș nasıl düşürülür" iken; COVID-19 döneminde "Ateș korona" sorgusunun en fazla oranda aratıldığ 1 görüldü. Kișilerin, COVID-19 pandemisi döneminde kendilerinde bulunan ve COVID-19 ile eșleștirdikleri semptomları sıklıkla sorgulattıkları ve kendilerinin hasta olup olmadıklarını belirlemeye çalıștıkları düșünülmektedir. Bulașıcı hastalıklar hakkında internet arama motorları ve sosyal medya aracılığıyla elde edilen bilgilerin, bu hastalıkların kontrolü ve önlenmesinde yardımcı olacağı bildirilmiştir
$(14,16,26)$. Bunun gibi salgın hastalıklar zamanında ilgili algoritmalar geliştirilip kullanımı sağlanırsa insanların doğru bilgiye ulaşması sağlanabilir, gerçekten hasta olma ihtimali olmayanların sağlık kaynaklarını gereksiz kullanmalarının önüne geçilebilir.

Dünya genelinde COVID-19 semptomlarına ilişkin internet sorguları konusunda gerçekleştirilen çalışmanın bulgularını doğrular nitelikte çalışmamızda, baş ağrısı, sırt ağrısı ve tat kaybı arasında pozitif ve anlamlı bir ilişki bulunmuștur $(r>0,40 ; p<0,01)(16)$. Buna ek olarak, COVID-19 semptomlarından olan ateş, öksürük ve nefes darlığı sorguları arasında da güçlü bir ilişki tespit edilmiştir $(r>0,60 ; p<0,01)(16)$.

COVID-19 pandemisi dalgalarının devam edeceği ya da mevsimsel salgınların olacağı bilinmektedir. $\mathrm{Bu}$ gibi salgınların gidişatlarını tahmin etmek için arama motorlarındaki sorgulamaların takip edilerek olabilecek koşullar hakkında önceden bilgi sahibi olmamızı ve gerekli önlemleri almamızı sağlayabilir. Bu tahminler aracıllı̆ıyla karar vericilerin sağllk hizmetini buna göre planlamasına olanak verebilir.

Medyada sıklıkla ve geniş bir şekilde yer alan hastalıkların bulunduğu veya nezle, grip gibi sezona bağlı hastalıkların arttığı dönemlere bağlı olarak internet üzerinden gerçekleştirilen sorgulama hacimlerinde de artış yaşanmaktadır. Bu durum, sağlık bilişimi açısından güçlü bir çevrimiçi teknolojik araç olarak kabul edilen Google Trends uygulamasiyla epidemiyoloji alanında geçekleştirilen sürveyans çalışmalarına da ivme kazandırmaktadır (27). Öte yandan, web madenciliği sağlık ve bilgi teknoloji alanında giderek yaygınlaşan bir alan olsa da, bu bilgi kaynağı halk sağlığı kurumlarının ve klinisyenlerin sahadan topladıkları epidemiyolojik verilerin değerlendirilmesinde ikame bir araç olarak değil, yardımcı bir araç olarak ele alınmasının doğru bir yaklaşım olacağı düşünülmektedir.

\section{SONUÇ}

İnternet arama motorlarında kullanılan anahtar kelimelerin aranma sıklığı, COVID-19 döneminde, öncesi döneme göre anlamlı olarak artmaktadır. Salgınların ve etkilerinin önceden tahmin edilmesi amaciyla arama motoru sorgularının analizi, gerekli tedbirlerin alınması ve karar vericilerin sağllk hizmetlerini etkin olarak planlamalarına imkân sağlayabilir.

\section{Kisitlılıklar}

Çalışmamız geriye dönük bir çalışmadır. Kullanıcıların COVID-19 semptomlarını sorgulamak amaciyla yukarıda belirtilen anahtar kelimeler dışında veya başka dillerde, başka kelimelerle veya jargonla sorgulama yapmış olması da mümkündür. İkincisi, Google Trend verileri saatlik, eş 
zamanlı veya daha kısa zaman birimleri içerisinde yapılan sorgulara ilişkin veri sağlamamaktadır. Bu durum, Google sorgu hacimlerinin zaman içerisindeki varyasyonunu daha spesifik olarak incelemeye ve ana kütlenin internetteki sorgu davranışlarını yakından incelemeye imkân tanımamaktadir.

\section{ETİK BEYANLAR}

Etik Kurul Onayı: Çalışma topluma açık olan Google arama motoru verileri ile yapıldığı için etik onaya ihtiyaç duyulmamaktadir.

Aydınlatılmış Onam: Çalışma retrospektif olarak dizayn edildiği için hastalardan aydınlatılmış onam alınmamıştır.

Hakem Değerlendirme Süreci: Harici çift kör hakem değerlendirmesi.

Çıkar Çatışması Durumu: Yazar(lar) bu çalışmada herhangi bir çıkara dayalı ilişki olmadığını beyan etmişlerdir.

Finansal Destek: Yazar(lar) bu çalışmada finansal destek almadıklarını beyan etmişlerdir.

Yazar Katkıları: Yazarların tümü; makalenin tasarımına, yürütülmesine, analizine katıldığını ve son sürümünü onayladıklarını beyan etmişlerdir.

\section{KAYNAKLAR}

1. Hocberg I, Allon R, Yom-Tov E. Assessment of the frequency of online searches for symptoms before diagnosis: analysis of archival data. J Med Internet Res 2020; 22: 1-7.

2. Kuehn BM. More than one-third of US individuals use the internet to self-diagnose. JAMA 2013; 309: 756-7.

3. Fox S, Duggan M. Pew Research Center's Internet \& American Life Project. Health Online 2013; 1-55.

4. Tonsaker T, Bartlett G, Trpkov C. Health information on the Internet: gold mine or minefield? Can Fam Physician 2014; 60: 407-8.

5. Smailhodzic E, Hooijsma W, Boonstra A, Langley DJ. Social media use in healthcare: A systematic review of effects on patients and on their relationship with healthcare professionals. BMC Health Services Research 2016; 16: 1-14.

6. Mosa AS, Yoo I, Sheets L. A systematic review of healthcare applications for smartphones. BMC Med Inform Decis Mak 2012; 1: $12-67$.

7. Perez J, Poon C, Merrifield R, Wong S, Yang, Guang-Zhong. Big Data for Health. IEEE J Biomed Health Informatics 2015; 19: 1193-208.

8. Jacobs W, Amuta AO, Jeon KC. Health information seeking in the digital age: An analysis of health information seeking behavior among US adults. Cogent Social Sci 2017; 3: 1-11.

9. Ginsberg J, Mohebbi MH, Patel RS, Brammer L, Smolinski MS, Brilliant L. Detecting influenza epidemics using search engine query data. Nature 2009; 457: 1012-14.

10. Martin SS, Quaye E, Schultz S, et al. Randomized controlled trial of online symptom searching to inform patient generated differential diagnoses. Digit Med 2019; 2: 1-6.

11.Paul MJ, Dredze M. Social monitoring for public health. USA: Morgan \& Claypool Publishers; 2017.
12. Mackintosh N, Agarwal S, Adcock K et al. Online resources and apps to aid self-diagnosis and help seeking in the perinatal period: A descriptive survey of women's experiences. Midwifery 2020; 90: $1-8$.

13. Cervellin G, Comelli I, Lippi G. Is Google Trends a reliable tool for digital epidemiology? Insights from different clinical settings. J Epidemiol Global Health 2017; 7: 185-9.

14.Li C, Chen LJ, Chen X, Zhang M, Pang CP, Chen H. Retrospective analysis of the possibility of predicting the COVID-19 outbreak from Internet searches and social media data, China, 2020. Euro Surveill 2020; 25: 1-5.

15. Rovetta A, Bhagavathula AS. COVID-19-related web search behaviors and infodemic attitudes in Italy: Infodemiological Study. JMIR Public Health Surveill 2020; 6: 1-8.

16. Higgins TS, Wu AW, Sharma D, et al. Correlations of online search engine trends with Coronavirus disease (COVID-19) Incidence: Infodemiology Study. JMIR Public Health Surveill 2020; 6: e19702.

17. Ciaffi J, Meliconi R, Landini MP, Ursini F. Google Trends and COVID-19 in Italy: Could we brace for impact?. Internal Emerg Med 2020; 15: 1555-9.

18. Effenberger M, Kronbichler A, Shin J, Mayer G, Tilg H, Perco P. Association of the COVID-19 pandemic with internet search volumes: a google trends analysis. Int J Infect Dis 2020; 95: 192-7.

19. Çra G, Birengel MS. COVID-19 genel klinik özellikler. In: Covid 19, Memikoğlu O, Genç V (editörler). Ankara Üniversitesi Basımevi; 2020: 43-9.

20.Bennett GG, Glasgow RE. The delivery ofpublic health interventions via the internet: Actualizing their potential. Annual Review of Public Health 2009; 30: 273-92.

21. Higgins O, Sixsmith J, Barry MM, Domegan C. A literature review on health information seeking behaviour on the web: a health consumer and health professional perspective. ECDC Technical Report Stockholm 2011; 1-12.

22. Kurian SJ, Bhatti AUR, Alvi MA et al. Correlations between COVID-19 cases and Google Trends data in the United States: a state-by-state analysis. Mayo Clin Proc 2020; 95: 2370-81.

23. Bento AI, Nguyen T, Wing C, Lozano-Rojas F, Ahn Y,Simon K. Evidence from internet search data shows information-seeking responses to news of local COVID-19 cases. PNAS 2020; 117: 11220-2.

24. Guan W, Ni Z, Hu Y et al. Clinical characteristics of coronavirus disease 2019 in China. N Engl J Med 2020; 382: 1708-20.

25. Bernardo SP, Anto A, Czarlewski W, Anto JM, Fonseca JA, Bousquet J. Assessment of the impact of the media coverage on COVID-19 -Releated Google Trends data: infodemiology study. J Med Internet Res 2020; 22: e19611.

26.Barros JM, Duggan J, Rebholz-Schuhmann D. The application of internet-based sources for public health surveillance (infoveillance): systematic review. J Med Internet Res 2020; 22: e13680.

27. Nuti SV, Wayda B, Ranasinghe I, Wang S, Dreyer RP. The use of Google Trends in health care research: a sistematic review. PLoS One 2014; 9: e109583. 